\title{
Vulnerability of Women in Situation of Violence in Specialized Service
}

Theme: Promotion and prevention.

Contribution to the discipline: The study presents the vulnerabilities of women in situation of violence. The results stimulate reflection on the manifestation of violence and reveal a social nature of a complex problem that affects the health of women. Besides, the study reinforces the need to consolidate progress in public policies for gender equality, eliminating all forms of violence and enhancing the empowerment of women.

\section{ABSTRACT}

Objective: To analyze the vulnerabilities of women cared for in a Reference Center to Women in Situation of Violence. Method: Qualitative study, from semi-structured interviews with 15 women, in 2017 and 2018. Data analysis occurred through thematic content analysis. Results: The category "vulnerability of women in situation of violence" covered social isolation, fear, or shame in denouncing, financial dependence, loss of freedom, fragile self-esteem, lack of formal support, decision to denounce and seeking help, interpersonal bond, protective measure, and difficulty of access to information. Conclusions: Vulnerability was apprehended in its individual and programmatic dimensions, inter-related with the social dimension. These vulnerabilities must be considered in the formulation of policies for care of women in situation of violence, given that it is the first step for gender equality and eliminate violence against women.

\section{KEYWORDS (SOURCE: DECS):}

Gender-based violence; violence against women; domestic violence; gender and health; health vulnerability; women's health.

\section{DOI: 10.5294/aqui.2019.19.2.2}

Para citar este artigo / Para citar este artículo / To cite this article

Paz PdO, Silva N, Becker L, Rigatto R. Vulnerability of Women in Situation of Violence in Specialized Service. Aquichan 2019; 19(2): e1922. DOI: 10.5294/aqui.2019.19.2.2

1 orcid.org/0000-0003-2944-7001. School of Nursing, Universidade Federal do Rio Grande do Sul, Brasil.

2 orcid.org/0000-0002-6582-6511. School of Nursing, Universidade Federal do Rio Grande do Sul, Brasil.

3 orcid.org/0000-0001-5850-7814. School of Nursing, Universidade Federal do Rio Grande do Sul, Brasil.

$4 \bowtie$ orcid.org/0000-0002-3893-2829. School of Nursing, Universidade Federal do Rio Grande do Sul, Brasil. regina.witt@ufrgs.br
Received: 13/01/2019

Sent to peer reviewers: 01/03/2019

Accepted by peers: 12/04/2019

Approved submission: 12/04/2019 


\section{Vulnerabilidad de mujeres en situación de violencia atendidas en servicio especializado}

\section{RESUMEN}

Objetivo: analizar la vulnerabilidad de mujeres atendidas en un Centro de Referencia de Atención a la Mujer en Situación de Violencia. Método: estudio cualitativo, a partir de entrevistas semiestructuradas con 15 mujeres en 2017 y 2018 . El estudio de los informes se realizó por análisis de contenido temático. Resultados: la categoría "vulnerabilidad de mujeres en situación de violencia" abarcó: aislamiento social, miedo o vergüenza por denunciar, dependencia financiera, pérdida de libertad, baja autoestima, ausencia de respaldo formal, decisión en denunciar y buscar ayuda, vínculo interpersonal, medida protección y dificultad en acceder a información pertinente. Conclusiones: la vulnerabilidad se aprehendió en la dimensión individual y programática y se interrelacionaron con la dimensión social. Estas vulnerabilidades deben considerarse en la formulación de políticas de atención a mujeres en situación de violencia, pues el primer paso para la igualdad de género es eliminar la violencia en contra de las mujeres.

PALABRAS CLAVE (FUENTE: DeCS)

Violencia de género; violencia en contra de la mujer; violencia doméstica; género y salud; vulnerabilidad en salud; salud de la mujer. 


\section{Vulnerabilidade de mulheres em situação de violência atendidas em serviço especializado}

\section{RESUMO}

Objetivo: analisar as vulnerabilidades de mulheres atendidas em um Centro de Referência de Atendimento à Mulher em Situação de Violência. Método: estudo qualitativo, a partir de entrevistas semiestruturadas com 15 mulheres, em 2017 e 2018. A análise das informações ocorreu por análise de conteúdo temática. Resultados: a categoria "vulnerabilidade das mulheres em situação de violência" abrangeu isolamento social, medo ou vergonha em denunciar, dependência financeira, perda da liberdade, autoestima fragilizada, ausência de apoio formal, decisão de denunciar e buscar ajuda, vínculo interpessoal, medida protetiva e dificuldade de acesso à informação. Considerações finais: a vulnerabilidade foi apreendida nas suas dimensões individual e programática, inter-relacionadas com a dimensão social. Essas vulnerabilidades devem ser consideradas na formulação de políticas de atenção a mulheres em situação de violência, pois o primeiro passo para a igualdade de gênero é eliminar a violência contra as mulheres.

PALAVRAS-CHAVE (FONTE: DeCS)

Violência de gênero; violência contra a mulher; violência doméstica; gênero e saúde; vulnerabilidade em saúde; saúde da mulher. 


\section{Introduction}

All forms of violence against women and girls represent a violation of human rights, and must be eliminated according to areas of action of the Sustainable Development Objectives for 2030, which require drastic advances in statistics, financing, and policies of gender equality (1).

Violence against women and girls is a global problem: One in every three women experiences physical or sexual violence throughout her life (1). From Latin America and the Caribbean, in 2017, Brazil had the highest absolute number of feminicide or femicide of women and girls over 15 years of age (1 133 for every 100000 women), followed by Mexico (760), El Salvador (345), and Argentina (251) (2).

The fifth among the 17 Sustainable Development Objectives for 2030, "Achieve gender equality and empower all women and girls", proposes guaranteeing the end of discrimination based on gender inequality through the search for equal rights and access to information, goods and services, and to the job market. It aims at the empowerment of women, through wage equality, as well as public policies that guarantee gender equality, avoid setbacks to women's rights, and promote the elimination of violence (3).

The potential for advancement towards substantive equality is greater when the claims of women and groups organized based on gender equity find receptivity in the diverse instances of power. Feminism that seeks equal rights (4), equality of opportunity between the sexes in the family and in society, is based on strengthening the autonomy of women. A society without gender inequalities is a reality one wishes to achieve (5).

The greater the disregard for human rights, the grater the possibility of a population to become ill (6). Violence compromises the physical, mental, and reproductive health of women, and can result in unwanted pregnancy, unsafe abortions, sexually transmitted diseases, and children with low birth weight. Hence, women in situation of violence use health services more frequently $(7,8)$.

Researching violence against women, under the focus of the concept of "health vulnerability", becomes relevant, because the context of a grievance and its interventions admit different evaluations. These depend on the theoretical and ethical-political perspective of whom describes them, as well as on the knowledge and tech- nological resources available or which are planned to become accessible (9). Thus, violence against women must be considered in relation to the susceptibility to this grievance and to lower availability of resources for their protection, in an individual, social, and programmatic mediation of the social policies (6).

Within the context of violence, the motivation strategies for coping are important to establish positive behaviors in the lives of women (10). In this sense, the Reference Centers are introduced as specialized services that promote the rescue of self-esteem to stimulate awareness, and reaching financial autonomy. Besides, it enables alternatives of encouragement to overcome violence and stimulate the creation of support links (11). In Brazil, the Reference Centers were implemented by the Secretary of Policies for Women, as essential structures of the Program for the Prevention and Coping with Violence against Women. From the Technical Standard of 2006, it aims to promote the rupture of the situation of violence and the construction of women's citizenship through interdisciplinary care and inter-sectorial articulation of services that integrate their network of care (12).

In this context, the aim of this article is to analyze the vulnerabilities of women cared for in a Reference Center to Women in Situation of Violence.

\section{Method}

Descriptive and exploratory study, of qualitative approach, based on the thematic content analysis technique by Minayo, was developed (13). Qualitative studies are based on the quest to understand in depth values, practices, logics of action, habits, beliefs, attitudes of groups with the degree of reality that cannot be quantified, which corresponds to the most profound space of relationships and phenomena that cannot be reduced to the operability of variables (13). The analysis is based on the interpretation of the research process, which seeks to comprehend in depth the vulnerability of women in situation of violence who decided to seek help.

The study had the participation of 15 women in a Reference Center of Care to Women in Situation of Violence (CRAM, for the term in Portuguese), of the municipality of Porto Alegre, Rio Grande do Sul, Brazil. The CRAM is the service of reference for the psychological and social care of these women. The sample was defined through data saturation (14). The women interviewed 
were indicated by the psychologists in the CRAM, with the concern of being in the monitoring phase, which represents the most advanced stage of follow up, when the women have better conditions of verbalizing about the violence, because, in the initial follow-up, the post-traumatic stress is quite present and it is perceived that talking about the experience of violence would not do the women well. The inclusion criterion was being women over 18 years of age and being cared in the CRAM; the exclusion criterion was being in the initial stage of care in the CRAM.

Information was collected during the second semester of 2017 and on the first of 2018, through semistructured interview. The interviews were conducted in the CRAM, in a room reserved to provide privacy to the participants; these lasted an average of 60 minutes and were recorded with the approval of the participants and completely transcribed.

The data obtained from the interviews were treated according to the technique of thematic content analysis, composed by the phases: a) pre-analysis, b) exploration of the material, and c) treatment of the results obtained (13). In the pre-analysis phase, an overview reading was conducted of the interviews to have better contact with the contents. In the sequence, we proceeded to capture the sense nuclei, grouping by affinity of common ideas, and elaborated a cutoff of the answers regarding the central research question with the aid of the NVivo software version 11; then, the general concepts that guided the analysis were categorized. Through exhaustive reading, theoretical questions were raised in order to have a better identification of the relevance of the content. During the exploration of the material, the common ideas reflected in these cuts were identified. Each interview was read and re-read fully to confirm if these ideas were expressed along the lines of the subjects. By reading the interviews, it was sought to identify the relationship of the categories among each other, thus, arriving at common and inter-related aspects. The classification stage permitted constructing the empirical category responsible for specifying the themes and theoretical concepts that guided the discovery and construction of the sense nuclei, which provide a basis for this analysis. The final analysis consisted of the treatment of the results obtained and their interpretation, trying to articulate the structured material of the interviews with specialized literature, seeking to identify the underlying content of what was manifested. The referential of vulnerability in health was adopted as an analytical category (9), upon substantiating and validating the knowledge of the object studied.
In relation to the ethical aspects, this study fulfilled the requirements for research with humans, recommended by the National Health Council, in accordance with Resolution 466/2012 (15), and was approved by the Research Ethics Committee at Universidade Federal do Rio Grande do Sul, under notion 2.546.536, Certificate of Presentation for Ethical Appreciation 68940717.3.0000.5347. All participants signed the Informed Consent Form, in duplicate, in two tracks, with one remaining with each participant. To preserve anonymity, participant identification was coded by the letters INT (interlocutor), followed by the number of the order of the interviews. After transcription, a second individual meeting was held with each participant to read and validate the transcripts. This allowed the participants to change their narration in the transcription and favored the reliability of the data.

\section{Results}

\section{Vulnerability of women in situation of violence}

Analysis of the information evidenced the vulnerabilities of the women in the individual and programmatic dimensions; having the social dimension of vulnerability manifested in the inequality of gender relations.

The maintenance of violence by an intimate partner relies on dynamics that presuppose social isolation and fear or shame in denouncing, as well as a restricted network of people who do not threaten the power of the perpetrator. This network is often characterized as fragile in the view of women and does not have the resources to offer support or openness to dialogue in case of need.

"I will be very sincere, I believed that violence was something very distant and that it happened in socially vulnerable places, I never thought it could happen to me in a relationship, but we do not choose, it just happens. And, when I found myself in a situation of violence, I could not believe what was happening, I felt very ashamed to talk about it with my family and friends." (INT 10)

Fear and financial dependence on the partner are the main reasons for not placing a complaint, given that the manifestation of fear seems to turn women into permanent hostages of violence and generates the submission to a cycle of violence sustained by economic insecurity. 
"I was afraid of getting separated and starving and not having enough money to support my daughter." (INT 12)

In addition to the restriction of ties, the strategy of male domination also occurs from the prohibition of the possibility of working, studying, choosing a religious orientation, even imposing distancing from family members, characterized as the loss of freedom.

"He controlled my schedules, the days of services, with whom I was talking, if I was on the phone he wanted to know and I had to put it on speaker, he wanted to hear what I was talking about. I never asked him to put his phone calls on speakerphone. I did not touch his phone, but he always touched mine." (INT 14)

"I think I need to have a strong inner strength to get out of this cycle and break the relationship, I still have not separated and this is damaging my health. I cannot sleep right, I cannot enjoy sex because I do not feel like it; I do it so he won't say I have a lover. Now, during the interview, he called me twice. I felt my mobile phone vibrate, but I am not going to answer." (INT 8)

Violence materializes domination in women's lives, its practice establishes physical and/or psychological control of their bodies and in how they think and act. Moreover, it reflects negatively and leads to sadness and indignation amid a set of feelings involved in a relationship in which they have fragile self-esteem about their identity and autonomy.

"I was very emotionally unbalanced, very exhausted and I got very fat. I felt like the ugliest woman in the world, my personal image was destroyed, I would lie down and did not want to leave the house. My mother encouraged me to get dressed, take care of my hair. I went to a beauty salon and the hairdresser destroyed my hair, I got really bad. I felt the way he said: Stupid, incompetent, and fat." (INT 12)

In another approach, interpersonal bonding as protection for women represents the possibility of having someone to talk to about violence, having support to denounce, to listen to advice and visualize the possibility of confrontation.

"He attacked me inside my mother's house and my brother and my eldest son defended me. He pushed me and threatened to punch me in the face, my brother and son noticed and did not let him, they talked to me and encouraged me to place a complaint." (INT 14)
"I have difficulty talking about what I went through. I felt sorry for not having someone to help me. I felt I did not want to involve my family in the violence that I was suffering. Now I can understand that if they had known what I was going through, they could have helped me. I told my father about the violence, but my father is very chauvinist and told me not to split up, not to give up the marriage, he said that I had to take care of my husband. I believed in my father and that's why the years went by and I delayed in denouncing." (INT 11)

With the guide of a social support network that promotes shelter and protection, the decision to complain and seek help becomes more accessible.

"I received a booklet on violence, so I recognized myself in that booklet and realized that I suffered psychological violence. The greatest act of courage I ever had in my life was to denounce and decide to seek help." (INT 6)

In the analysis of the testimonies, isolation, fear and shame appear as important barriers in the search for help. Another aspect related to the individual vulnerability is the difficulty of access to information, which keeps women from being able to visualize ways of coping. Support and access to information are fundamental to manage to seek help. With the support of a network of services and legislation providing support to women in situation of violence, it is possible to establish the confrontation.

"I got separated in 2007, the Maria Penal Law came into force in 2006. At that time, this Law was not so publicized and I did not have so much information, it could have more disclosure maybe even be shown on television. I believed that the Law was for very serious cases of physical aggression or death threats and did not know how it worked to achieve a protective measure. I did not know that I could denounce the psychological aggression I suffered, if I had known, I would have denounced a long time ago." (INT 6)

For women in situation of violence, the protective measure, supervised by the Public Security Service, is an assurance that guarantees to distance the perpetrator and punishes with imprisonment not obeying the judicial mandate. Many times, for fear of being arrested, the aggressor ends up moving away from home. In this perspective, the protective measure is an effective strategy for coping with and preventing re-victimization. 
"He started to shake the light pole in front of my house, I was worried about a short circuit and called the police. He kept waiting for the police and said 'you can call, because it won't work, I won't be arrested'. The police arrived and talked to him, said that he could be arrested if he did not leave, but he paid no attention. The policeman asked me if I wanted him arrested because of the protective measure, I said, 'Yes, you can arrest him', because I got tired and there is the law, he's threatening me and my family. We went to the police station to file the complaint and then he was taken to jail. He stayed in jail for 15 days. We had to build a wall in my house so he did not have more access, with the wall we have more protection." (INT 15)

Lack of informal support hinders women from seeking help, but the lack of formal support weakens the confrontation of violence. When looking for services, many women still experience situations based on a reproduction of the relational patterns derived from gender inequalities, which disqualify them and make them feel inferior.

"I went to the police station near my house to report it, but the police officer did not believe me and treated me very badly, he said that I would end up going back to my ex-husband. He embarrassed me when he said this because he spoke loudly in front of other people at the police station. He said: 'Look, now she comes to report, but at night she goes to sleep with him again'. I answered: 'Are you kidding me, do you think my life is worthless? I would not come here and say that I was threatened with death if it were not true and yet you believe I'm joking?' And he responded: 'Maybe, but there are many women who come here to complain and the next day they are back with the aggressor'. He filled out the occurrence bulletin, but did not advise me that I should seek a protective measure in the justice forum." (INT 15)

Likewise, it is important to consolidate a space for women's services in an integrated manner, avoiding their spending time in traveling in search of help.

"There was a day that my son asked me what was missing so I could get separated and I said I needed time, because to solve this I would have to go to many places and I would have to walk a lot, probably I would lose a whole day to solve, walking from one place to another. The police station and the Forum are distant places and there isn't a single service for me to report the violence, to get a protective measure and start the separation process. In addition, I needed psychological help and I searched for the CRAM. Going to all these places, I would lose a lot of time with displacement" (INT 3).

\section{Discussion}

Individual and programmatic vulnerability characteristics articulate and constitute social vulnerability based on gender inequality. This is reinforced by male domination in which men feel ownership of women and impose control over their behavior, dress, with whom they relate, and about their money. Individual vulnerability is constituted as women losing their freedom, their autonomy to come and go, to decide the best for themselves (16). In addition, by establishing distance from close individuals, women become isolated and, if there is a situation of violence, it is more difficult to establish coping means.

The isolation of women happens often through fear of frequent threats and aggressions, and the shame that keeps them from talking about the violence suffered, influencing their decision to denounce. Contacts, friendships, and close bonds are avoided when considered unwanted by the husband due to the fear of originating possible aggression, which causes in women the attitude to seek refuge in silence and isolation (17). Fear of reporting becomes a barrier to overcoming violence, regardless of social status and emotional fragility, which is characterized as an individual vulnerability (18).

Financial dependence, lack of family support, and social isolation also limit the autonomy of women because, without support, they cannot visualize strategies of coping and protection due to the psychological dependence (19). With this, it is considered that the physical and psychological recovery of women is only possible when they can break away from the violent relationship (20). Thus, the dimension of individual vulnerability involves the social vulnerability, structured in gender inequality in which women have no financial independence and social support.

Additionally, the programmatic dimension of vulnerability should be considered in the search for help. The lack of a specialized network in caring for women can influence negatively on the decision to seek help, as well as lead women to suffering, either through insecurity in exposing their lives to others or through the endless paths that run through the trajectory of seeking solutions to the situation of violence (21).

Lack of preparation of professionals and services due to the naturalization/invisibility of violence generates discrimination in which professionals put the blame on women for the situation in 
which they live and underestimate their suffering (22). In these circumstances, women no longer believe in such services because they suffer from secondary victimization (also called institutional violence), which is carried out by public agents and creates gaps in the network of legal and social assistance, public safety or health services, which should provide formal care and support (23). In this context, it is important to ensure policies and laws that rigorously punish acts of violence and ensure adequate intervention and care services (24).

Absence of professional qualification compromises service. It is not only a matter of mastering administrative procedures or care techniques, but to know the specificities of violence based on gender. The lack of professional specialization is an obstacle to women's access (25), a programmatic vulnerability that may occur at different times in the search for help.

Addressing programmatic vulnerability, therefore, requires drastic progress in gender equality policies. Thus, government must be responsible for regulating public policy of social equity and empowering women whose concern is to combat violence and provide intervention tools (26). Violence needs to be an object in the formulation of policies that cover the operationalization of actions in health and strengthen good practices for the care and training of professionals (27).

Caring for women in situation of violence requires the integration of multi-professional work (28), which needs dialogue and planning between services and care professionals, permeating communication to avoid the fragmentation of care. This occurs when the professional meets only its demand, with difficulty in evaluating each case in extended manner and perceiving the real needs of women (29). In order to place the complaint, it is important that a network of care be provided to ensure follow-up and support for women to promote prevention and coping with violence. In addition to being assisted by the judicial system, in many cases, they need access to the health system, given that many seek care in these services before they arrive at a police station to complain (26). The absence of specialized services constitutes programmatic vulnerability that prejudices women in seeking help.

As a way to meet the needs of women, since 2013, in some Brazilian capitals, the Brazilian Women's House was created, linked to the Program Women: Living without Violence. These services contribute to facilitating assistance, by promoting the integration of women's services, and focus on integral care (30), consolidating different options in a single space, which allows women not to waste time traveling in search of help. The Program remains in effect, but in many capitals it has not been implemented and there is still no integrated physical space for service, which turns the situation into a programmatic vulnerability.

In Brazil, progress to combat violence against women are the Maria da Penha Law and the Feminicide Law. The development of legislation that punishes violence and protects women is essential in addressing programmatic vulnerability. In addition, the importance of the protective measure as a right of women who denounce violence to ensure the legal support of protection and distancing of the perpetrator is emphasized (31). This distancing is fundamental and guaranteed by the protective measure, because to continue living in the same place with the perpetrator makes women susceptible to future repetition of violence (20).

Another important action in this context was the creation, in 2003, of a Secretary of Policies for Women, later linked to the Ministry of Human Rights, whose focus is to coordinate management of public policies to ensure that governmental spheres assume the responsibility for the reduction of violence and strengthen gender equality (32). Thus, it is possible to establish the programmatic confrontation of violence based on current legislation and a specialized services network that ensures the refuge and protection of women.

Within the scope of collective health, it is necessary to consolidate the promotion of health through the mobilization of various government agencies against violence, in an intersectoral context of social visibility. This would strengthen the construction of care networks and mobilize civil society in participatory instances, in order to promote debates of the social problem in the search of solutions to confront violence against women $(33,34)$.

In addition, it is imperative to ensure the support and security of women and their children by investing in training programs in different sectors of society, especially in the judicial, for the correct application of protection laws and to strengthen care systems that involve taking action in care, within the health system, to reinforce the detection of violence in primary care. At the same time, it is necessary to develop government awareness campaigns in partnership with feminist organizations with a focus on gender equality (34). 
These results evidence actions that, according to the United Nations, in the 2030 agenda, are urgent to confront violence against women and achieve gender equality. For this, four actions are configured in the public spheres: Implementation and enforcement of comprehensive laws and policies; universal attention to intersectoral and quality services in support of women; social awareness and prevention measures to combat underlying factors and root causes of violence; and compilation of databases on violence (1), consolidating epidemiological surveillance by structuring and strengthening observatories of violence. Concern to develop such actions demonstrates the government's initiative to eliminate violence against women.

\section{Conclusions}

Analysis of women's vulnerabilities when cared for in a Reference Center to Women in Situation of Violence evidenced elements of their individual dimension, such as: Social isolation, fear, shame of denouncing, financial dependence, loss of freedom, fragile self-esteem, lack of support, and difficulty of access to information. Confronting these difficulties revealed actions related to the programmatic dimension, because when deciding to denounce and seek help, having an interpersonal bond as social support, women obtained protection through a legal measure. In addition, women need financial independence, to regain their self-esteem and their physical and mental health, making it necessary to (re)organize their lives in the initiative of empowering themselves to cope and overcome violence.

Within the context studied, vulnerability revealed subjective aspects of the women, as well as programmatic and social components, with emphasis on the connections among individuals, in their community relations, in the socio-cultural and economic context. The mismatch among the actions undertaken to meet the demands of the women was evidenced, which reinforces the importance of integrating the services network to address gender violence.

In the governmental setting, it becomes essential to create legislation that protects women from violence, which goes beyond punitive actions. It is essential to develop projects to promote gender equality and the articulation of different sectors of society to debate about violence, which would generate visibility to this serious social problem. By mobilizing society, it is possible to strengthen the network of services, in inter-sectorial manner, from the perspective of integral care of women in situation of violence.

In this sense, the recognition of vulnerabilities should be considered in the formulation of policies for care, to support the fifth Objective of Sustainable Development, since the first step for gender equality is the elimination of violence against women.

The limitation of the study is related to the context of the source of the information: Women attending a Reference Center. For future studies, it is important to investigate attendance to other services of the network and to approach the dialogue among the professionals from the inter-sectorial perspective of the service.

The vulnerabilities of women in situation of violence, apprehended in their individual and programmatic dimensions, are interrelated with the social dimension. The importance of confronting violence, both in its macrosocial dimension, as part of a transformation structure, and in its microsocial dimension, based on behaviors whose senses are socially and culturally constructed, is reaffirmed. In the formulation of public policies, these cannot be confined to merely confronting violence, but to ensuring gender equality and avoiding setbacks as a result of such discrimination.

Conflict of interest: None declared. 


\section{References}

1. ONU Mujeres. Hacer las promesas realidad: la igualdad de género en la agenda 2030 para el desarrollo sostenible. Nova York: Nações Unidas; 2018. Available from: http://www.unwomen.org/-/media/headquarters/attachments/sections/ library/publications/2018/sdg-report-gender-equality-in-the-2030-agenda-for-sustainable-development-2018-es. pdf?la $=$ en $\& v s=834$

2. Observatorio de Igualdad de Género de América Latina y el Caribe. Feminicidio. Naciones Unidas; 2017. Available from: https://oig.cepal.org/es/indicadores/feminicidio

3. United Nations. Transforming our world: the 2030 Agenda for Sustainable Development. Nova York: The General Assembly. 2015. Available from: https://sustainabledevelopment.un.org/post2015/transformingourworld

4. Benedicto C. Malestares de género y socialización: el feminismo como grieta. Rev. Asoc. Esp. Neuropsiq. 2018; 38(134):607-25.

5. Alves JED. Desafios da equidade de gênero no século XXI. Rev. Estud. Fem. 2016; 24(2):629-38. Available from: http:// www.scielo.br/pdf/ref/v24n2/1805-9584-ref-24-02-00629.pdf

6. Paiva V. Psicologia na saúde: sociopsicológica ou psicossocial? Inovações do campo no contexto da resposta brasileira à AIDS. Temas psicol. 2013; 21(3):531-49. Available from: http://pepsic.bvsalud.org/pdf/tp/v21n3/v21n3a02.pdf

7. García-Moreno C, Zimmerman C, Morris-Gehring A, Heise L, Amin A, Abrahams N et al. Addressing violence against women: a call to action. Lancet. 2015; 385(9978):1685-95. Available from: https://ac.els-cdn.com/S0140673614618304/1-s2.0S0140673614618304-main.pdf?_tid=a2fa6e57-1 ce1-42a2-a0f9-d98ebcf3055e\&acdnat=1538422246_c3316d66b67e0216dae7cd2ef241e5db

8. Sánches LS. Resiliencia en violencia de género. Un nuevo enfoque para los/las profesionales sanitarios/as. Journal of Feminist, Gender and Women Studies. 2015; (1):103-13.

9. Ayres JR, Paiva V, França Junior I. Conceitos e práticas de prevenção: da história natural da doença ao quadro da vulnerabilidade e direitos humanos. In: Paiva V, Ayres JR, Buchalla CM. editores. Vulnerabilidade e direitos humanos: prevenção e promoção da saúde (Livro I). Curitiba: Juruá; 2012. p. 71-94.

10. Pereira JLF, Oliveira CDB, Freitas FFQ, Castro AP, Nóbrega MF, França ISX. Perfil da violência contra as mulheres atendidas em um centro de referência. Rev enferm UFPE. 2015; 9(Suppl. 6):8665-72. Available from: https://periodicos.ufpe. br/revistas/revistaenfermagem/article/view/10643/11655

11. Albuquerque Netto L, Moura MAV, Silva GF, Penna LHG, Pereira ALF. Mulheres em situação de violência pelo parceiro íntimo: tomada de decisão por apoio institucional especializado. Rev Gaúcha Enferm. 2015; 36(esp):135-42. Available from: http://www.scielo.br/pdf/rgenf/v36nspe/0102-6933-rgenf-36-spe-0135.pdf

12. Secretaria de Políticas para as Mulheres (BR). Norma técnica de uniformização: centros de referência de atendimento à mulher em situação de violência. Brasília: Secretaria Especial de Políticas para as Mulheres; 2006. Available from: http://www.observatoriodegenero.gov.br/menu/publicacoes/outros-artigos-e-publicacoes/norma-tecnica-de-uniformizacao-centros-de-referencia-de-atendimento-a-mulher-em-situacao-de-violencia

13. Minayo MCS. O desafio do conhecimento - pesquisa qualitativa em saúde. 14a . São Paulo: Hucitec; 2014.

14. Minayo MCS. Amostragem e saturação em pesquisa qualitativa: consensos e controvérsias. Revista de Pesquisa Qualitativa. 2017; 5(7):1-12. Available from: https://edisciplinas.usp.br/pluginfile.php/4111455/mod_resource/content/1/ Minayosaturacao.pdf

15. Ministério da Saúde (BR). Resolução n. ${ }^{\circ} 466$ de 12 de dezembro de 2012. Aprova diretriz e normas regulamentadoras de pesquisas envolvendo seres humanos. Conselho Nacional de Saúde. Brasília; 2012.

16. Tejada SC, López GM. Mujeres, diversidad funcional y multidiscriminación. Journal of Feminist, Gender and Women Studies. 2018; (7):45-56.

17. Dutra ML, Prates PL, Nakamura E, Villela WV. A configuração da rede social de mulheres em situação de violência. Ciênc. Saúde Coletiva. 2013; 18(5):1293-304. Disponível em: http://www.scielo.br/pdf/csc/v18n5/14.pdf 
18. Terra MF, d'Oliveira AFPL, Schraiber LB. Medo e vergonha como barreiras para superar a violência doméstica de gênero. Athenea Digital. 2015; 15(3):109-25.

19. Seidl MA, Benetti SPC. Fatores de risco e mecanismos de proteção nas narrativas das famílias em situação de violência conjugal. Aná. Psicológica. 2011; 29(2):247-57. Available from: http://www.scielo.mec.pt/scielo.php?script=sci_artte xt\&pid=S0870-82312011000200005

20. Sanchez-Lorente S, Blasco-Ros C, Martínez M. Factors that contribute or impede the physical health recovery of women exposed to intimate partner violence. Women's Health Issues. 2012; 22(5):491-500. Available from: https://doi. org/10.1016/j.whi.2012.07.003

21. Grossi PK, Coutinho ARC. Violência contra a mulher do campo: desafios às políticas públicas. Serv. Soc. Rev. 2017; 20(1):25-40. Available from: http://www.uel.br/revistas/uel/index.php/ssrevista/article/view/32071/23366

22. Silva EB, Padoin SMM, Vianna LAC. Mulher em situação de violência: limites da assistência. Ciên. Saúde coletiva. 2015; 20(1):249-58. Available from: http://www.scielo.br/pdf/csc/v20n1/pt_1413-8123-csc-20-01-00249.pdf

23. Cisne M, Oliveira GMJC. Violência contra a mulher e a lei Maria da Penha: desafios na sociedade patriarcal-racista-capitalista do estado brasileiro. Serv. Soc. Rev. 2017; 20(1):77-96. Available from: http://www.uel.br/revistas/uel/index. $\mathrm{php} / \mathrm{ssrevista/article/view/32465/23369}$

24. Organización Mundial de la Salud (OMS). Respuesta a la violencia de pareja y a la violencia sexual contra las mujeres: directrices de la OMS para la práctica clínica y las políticas. Washington: OPS; 2014. Available from: http://iris.paho. org/xmlui/bitstream/handle/123456789/7705/WHORHR13_10_esp.pdf?ua=1

25. Pasinato W. Acesso à justiça e violência doméstica e familiar contra as mulheres: as percepções dos operadores jurídicos e os limites para a aplicação da Lei Maria da Penha. Rev. direito GV. 2015; 11(2):407-28. Available from: http:// www.scielo.br/pdf/rdgv/v11n2/1808-2432-rdgv-11-2-0407.pdf

26. Schraiber LB, d'Oliveira AFPL, Portella AP, Menicucci E. Violência de gênero no campo da saúde coletiva: conquistas e desafios. Ciênc. Saúde Coletiva. 2009; 14(4):1019-27.

27. Escorsim SM. Violência de gênero e saúde coletiva: um debate necessário. Rev. Katálysis. 2014; 17(2):235-41.

28. Provecho ABA, Pilo GP, Pino CG. Violencia de pareja hacia la mujer y profesionales de la salud especializado. Anal. Psicol. 2018; 34(2):349-59.

29. Vieira EM, Hasse M. Percepções dos profissionais de uma rede intersetorial sobre o atendimento a mulheres em situação de violência. Interface (Botucatu). 2017; 21(60):51-62. Available from: http://www.scielo.br/pdf/icse/v21n60/18075762-icse-1807-576220150357.pdf

30. Cerqueira D, Lima RS, Bueno S, Neme C, Ferreira H, Coelho D et al. Atlas da violência 2018. Rio de Janeiro: IPEA e FBSP; 2018.

31. Casa Civil (BR). Subchefia para Assuntos Jurídicos. Decreto n. ${ }^{\circ}$ 8.086, de 30 de agosto de 2013. Institui o Programa Mulher: Viver sem Violência e dá outras providências. Brasília (DF): Casa Civil; 2013. Available from: http://www.planalto. gov.br/ccivil_03/_ato2011-2014/2013/decreto/d8086.htm

32. Casa Civil (BR), Subchefia para Assuntos Jurídicos. Lei n. ${ }^{\circ} 13.641$, de 3 de abril de 2018. Brasília: Casa Civil; 2018. Available from: http://www.planalto.gov.br/ccivil_03/_ato2015-2018/2018/lei/L13641.htm

33. Romero LMK, Muñoz CM, Henríquez MC, Higueras AS, Ancalaf AT, Nitrihual L et al. Modelo participativo para el abordaje de la violencia contra las mujeres en la Araucanía, Chile. Rev Panam Salud Publica. 2017; (41):1-4.

34. Navarro-Mantas L, Velásquez MJ, Lemus S, Megías JL. Prevalence and sociodemographic predictors of intimate partner violence against women in El Salvador. J Interpers Violence. 2018; June 13. Available from: https://doi. org/10.1177/0886260518779065 [Epub ahead of print]. 